KYIV-MOHYLA

Humanities JouRnaL

KYIV-MOHYLA SCHOLARLY PEER-REVIEWED JOURNALS

Kyiv in the Global Biblical World: Reflections of KTA Professors From the Second Half of the 19th and Early 2oth Centuries

Author(s): Sergiy Golovashchenko

Source: Kyiv-Mohyla Humanities Journal 5 (2018): 37-59

Published by: National University of Kyiv-Mohyla Academy

http://kmhj.ukma.edu.ua/ 


\title{
Kyiv in the Global Biblical World: Reflections of KTA Professors From the Second Half of the 19th and Early 2oth Centuries
}

\author{
Sergiy Golovashchenko \\ National University of Kyiv-Mohyla Academy, \\ Department of Philosophy and Religious Studies
}

\begin{abstract}
The focus of this article is the global and European experience of the reception, assimilation, and social application of the Bible, reproduced in the works of a number of prominent Kyiv Theological Academy (KTA) representatives from the second half of the 19th and early 2oth centuries. The analysis specifically covers the works of professors Stefan Solskyi, Kharysym Orda, Nikolai Drozdov, Afanasii Bulgakov, Mykola Makkaveiskyi, Vasylii Pevnytskyi, Arsenii Tsarevskyi, Volodymyr Rybinskyi, Dmytro Bohdashevskyi, and Aleksandr Glagolev. The author uses the metaphor of the Biblical world to describe the historically developed spiritual and cultural component of the European world, for which the Bible played the role of a normative and symbolic core. Affiliation with the Biblical world — as a way of broad social application of the Bible and assimilation of the norms and public behaviors sanctioned by this text - was and still is a stable symbolic marker as well as a cultural and ideological factor of integration with European civilization. The historical panorama of the reception of Biblical knowledge and the inculturation of Biblical morality by Christianized nations, reproduced in the writings of Kyiv academics, is presented as a field of centuries-old intercultural contacts and active inter-confessional interaction, and as an important ideological and moral factor of the socio-political integration and development of civil society. The issues addressed by Biblical studies in Europe and the rest of the world and considerations and solutions prompted by these issues proved to be fruitful for both the academic research and public practices in which academics of the Kyiv Theological Academy were engaged. The past and modern foreign experience related to the inculturation of the Bible was interpreted by the Kyiv researchers in the local context, more specifically, in the modernization attempts of the 19th and early 2 oth centuries. Therefore, the reflection of European and worldwide experience, though not fully implemented, was productive and was a potential factor that could have contributed to the European modernization of Kyiv cultural and religious life of the time and its integration into the global Biblical World.
\end{abstract}

Key Words: Bible, Bible studies, Biblical world, European civilization, modernization, Kyiv Theological Academy. 


\section{Introduction}

The assimilation of the Bible as a sacred text dominant in a certain local denominational culture implies, in addition to liturgical application, the inculturation of the norms and styles of social behavior legitimized by this text outside of liturgical use. Such broad social assimilation and use of the Bible was, and still is, a firm sign of affiliation with the European world in all its manifestations. One may argue that today's European world, even as globalized a concept as it currently is, has historically developed as the embodiment of an ideal symbolic Biblical world, while the Biblical world, as a focus of norms and symbols, has been socially institutionalized in various forms. With the spread of Christianity, the Biblical world underwent globalization, which overrode local restrictions pertaining to religious practices, ethnic identities, and socio-political institutions.

Ukraine has been immersed in the Christianized world for over a thousand years, and despite its diversity in territorial and political configurations, it affiliated itself with the Biblical world. This identity has become an extremely important symbolic marker as well as a cultural and ideological factor of civilization. The incorporation of the Biblical text, both as a sacral centre of liturgical practices and a source of social and cultural practices, including ethical, legal, political, and even commercial ones, took place at different periods of time at various levels and in different types of social institutions. These levels and types include liturgical and paraliturgical church practices, moral and ethical family practices related to the upbringing of children, the schooling system with its role of instilling moral and civil virtues, and even government ideology and propaganda. This spectrum of channels, thus, which exist in the national culture and facilitate the collective and individual incorporation of both the direct and symbolic content of the Bible as well as various practices encoded in it, should be taken into account as an inseparable component of the developing Ukrainian identity.

The continuous reception and assimilation of the global, primarily European, experience of reading the Bible, and the social implementation of Biblical practices, took place on Ukrainian soil in various historical periods through the efforts of our ancestors, who worked in various cultural and religious centers and loci. The Kyiv cultural and religious center emerged through the gradual continuity and interplay of its historical periods, among which we especially distinguish the Kyivan Rus period, the (pre-Mohyla) Lithuanian Rus period, the (Kyiv-Mohyla Academy) Mohyla period, and the (Kyiv Theological Academy, 19th through the early 2oth centuries) Academy period. This center played probably the most important role in the development of Ukrainian Biblical practices and the integration of domestic culture and spirituality into the global Biblical world.

Such integration became particularly systematic during the last two of the listed stages - the Mohyla period and the Theological Academy one. Our previous study 
of these stages ${ }^{1}$ has shown that the development of the Kyiv tradition of Biblical Studies was accompanied by potent reflection by researchers of domestic and foreign experience, especially from the second half of the nineteenth century. Several prominent Kyiv scholars, in their works, analyzed the history of how the Bible was integrated in Ukrainian culture and how the Biblical text functioned in the Ukrainian cultural and public environment. Priority consideration was given to Orthodox components of the national spirituality, which developed in the Russian Empire. However, it should be noted that domestic experience was explored and analyzed through the prism of intensive comparison with the global and European experience of societal incorporation of the Bible, i. e. experience that predominantly belonged to other denominations.

In previous research, we have already discussed Kyiv researchers of the 19th and early 2oth centuries and their critical reception of the foreign experience of academic Biblical studies pertaining to other denominations with regard to apologetic theology and critical science. ${ }^{2}$ We have also explored certain issues relating to the popularization of the Biblical text and knowledge about it, albeit in connection with Orthodox ecclesiastical (liturgical) and paraliturgical practices, such as preaching practices, religious education practices, and missionary activity. ${ }^{3}$ We have also analyzed the use

See: S. I. Golovashchenko, Doslidzhennia ta vykladannia Biblii v Kyivskii dukhovnii akademii $X I X$ - pochatku XX st. [Research and Instruction of the Bible at the Kyiv Theological Academy in the 1gth and Early 2oth Centuries] (Kyiv: Vydavnychyi viddil Ukrainskoi Pravoslavnoi Tserkvy, 2012); S. I. Golovashchenko, "Pro rol 'Mohylianskoi doby’ v stanovlenni i rozvytku kyivskoho dukhovno-akademichnoho bibliieznavstva [The Role of the 'Mohyla Era' in the Evolution and Development of Kyiv Theological-Academic Biblical Studies]," Trudy Kyivskoi Dukhovnoi Akademii 19 (2013): 100-07; Sergiy Golovashchenko, "Biblical Studies at the Kyiv Theological Academy (19th - early 2oth Centuries): The Results and Prospects of the Research," Kyiv-Mohyla Humanities Journal 2 (2015): 11-30, accessed October 5, 2015, DOI:10.18523/ KMHJ51019.2O15-2.11-30.

Sergij Gołowaszczenko, "Recepcja europejskiej krytyki biblijnej w Akademii Kijowskiej. Wymiar hermeneutyczny a ideologiczny," 191-200; S. I. Golovashchenko, “Apologeticheskii komponent v rabotakh bibleistov Kievskoi dukhovnoi akademii kontsa 19-nachala 20 st. (K probleme sopostavleniia bogoslovskogo i nauchnogo diskursov) [The Apologetic Component in the Works of Biblical Scholars of the Kyiv Theological Academy of the Late 19th and Early 2oth Centuries (Comparing Theological and Academic Discourses)]," Vestnik Pravoslavnogo Sviato-Tikhonovskogo gumanitarnogo universiteta 3.47 (2013): 6o-74.

S. I. Golovashchenko, "Pravila dlia rukovodstva pri sostavlenii obiasnitelnykh primechanii k russkomu tekstu Biblii Ya. O. Olesnitskogo: peredistoriia rosiskoi tlumachnoi Biblii [Guidelines for the Preparation of Explanatory Notes to the Russian Text of the Bible by Ya. O. Olesnitskii: Background of the Russian Interpretational Bible]," Naukovi zapysky NaUKMA 50 (2006): 56-63; S. I. Golovashchenko, "Bibliia yak predmet populiarnoho vyvchennia: kyivska viziia kintsia 19-pochatku 20 st. (Volodymyr Rybynskyi) [The Bible as a Subject of Popular Study: The Kyivan Vision of the Late 19th and Early 2oth Centuries (Volodymyr Rybinskyi)]," 
of foreign practices in local Biblical studies as a contributing factor in the evolution of a specifically Eastern Slavic Orthodox identity. ${ }^{4}$

We believe it is now time to somewhat expand the scope of our research and look beyond the limits of the reflections of Kyiv scholars of the second half of the 19th and early 2 oth centuries, in which they compared the domestic and foreign experience of using the Bible in theological education, ecclesiastic enlightenment, upbringing, and missionary activity. At this stage, we would like to focus on evidence pointing to the significance of the global and European experience in using the Biblical text and Biblical knowledge in the broadest social and cultural contexts. We have in mind the incorporation of Biblical normative and symbolic resources as a factor that shaped not only the denominational Orthodox identity but also the general civic identity, elements of civil society, and even the political nation in Ukraine, notwithstanding paradoxical social and political circumstances. It is important to emphasize the assumption that the Bible performed this role even during the denationalization of Ukrainian ethnicity and the absence of statehood.

In this article, therefore, we will try to shed light on the legacy of renowned KTA Biblical scholars of the second half of the 19th and early 2oth centuries from a somewhat different angle, taking a fresh look at a number of their works from the perspective of the above stated goals and considerations. We will consider several theological and historical essays by Prof. Stefan Solskyi as sources for further analysis. In these works he discussed the history of the assimilation of the Bible mainly in the Orthodox Ukrainian lands, but in a broad European context, while also describing specific aspects of Ukrainian cultural and social development. ${ }^{5}$

Other important sources include the few, however significant, articles written by S. Solskyi and number of his colleagues (Aleksandr Voronov, Nikolai Drozdov, Afanasii

Kyivska Akademiia 8 (2010): 44-50; S. I. Golovashchenko, "Mizh akademichnym vyvchenniam i misionerskoiu populiaryzatsiieiu Biblii: "osoblyva dumka” profesora Volodymyra Rybinskoho [Between Academic Study and Missionary Popularization of the Bible: 'The Specific Opinion' of Professor Volodymyr Rybinskyi]," Naukovi zapysky NaUKMA 141 (2013): 23-31. Sergiy Golovashchenko, "Orthodox Christian Biblical Studies in Pursuit of Identity: The Role and Impact of Personal Research Practices," Kyiv-Mohyla Humanities Journal 3 (2016):105-21, accessed July 28, 2016, DOI:10.18523/kmhj73944.2016-3.105-121.

S. M. Solskii, "Upotreblenie i izuchenie Biblii v Rossii ot krescheniia Rusi i do 15 v. [The Usage and Study of the Bible in Russia from the Christianization of Rus Through the 15 th Century]," Pravoslavnoe obozrenie 27.10 (1868): 145-80; 27.11 (1868): 251-70; S. M. Solskii, "Obozrenie trudov po izucheniiu Biblii v Rossii s 15 veka do nastoiaschego vremeni [Review of Research Works on the Bible in Russia from the 15th Century to the Present]," Pravoslavnoe obozrenie 1.2 (1869): 190-221; 1.4 (1869): 538-77; 1.6 (1869): 797-822; S. M. Solskii, "Ostrozhskaia Bibliia v sviazi s tseliami i vidami yeia izdatelia [The Ostroh Bible in Connection with the Intentions and Views of Its Publisher]," TKDA 7 (1884): 293-320; S. M. Solskii, "Ob uchastii imperatora Aleksandra I v izdanii Biblii na russkom yazyke [The Participation of Aleksandr I in the Publication of the Bible in the Russian Language]," TKDA 1 (1878): 172-96. 
Bulgakov, Mykola Makkaveiskyi, Vasylii Pevnytskyi) during the 186os through the 189os and early 1900 s with regard to the social status of the Bible and Biblical knowledge, as well as the distinction between the European ideological and cultural situation and the domestic Russian one (which at that time included Ukraine) ${ }^{6}$

We will review studies by Volodymyr Rybinskyi, exemplary and quite unique for the beginning of the 2oth century, in which he thoroughly analyzed Western assimilation of the Bible, and used vivid examples to illustrate the peculiarities of its use in the West in various areas, not just pertaining to religion and church, but also related to education, the civil political field, as well as a mundane family environment. ${ }^{7}$ Prof. Dmytro Bohdashevskyi (later known as Archimandrite, then Bishop Vasilii) and Archpriest Aleksandr Glagolev addressed a number of specific issues related to the use of the Bible in connection with vital moral, social, economic, and political problems of contemporary society (primarily taking into account the situation specific to Kyiv, and Ukraine). ${ }^{8}$

Finally, a wide range of facts and evaluations presented in different years of the second half of the 19th and early 2oth centuries by S. Solskyi, Kharysym Orda, Arsenii Tsarevskyi, V. Rybinskyi, A. Glagolev, and D. Bohdashevskyi, using the genre

6 A. Voronov, "Zametki iz tserkovnoi zhizni Zapada (otritsatelnye napravleniia v sovremennom khristianstve) [Notes on the Church Life of the West (Negative Trends in Modern Christianity)]," TKDA 6 (1866): 231-54; N. Drozdov, "Zaprosy sovremennoi zhizni v otnoshenii k bogoslovskoi nauke [The Demands of Modern Life in Relation to Theological Studies]," TKDA 10 (1885): 21030; S. Solskii, "Tserkovno-prikhodskaia shkola [The Church Parish School]," TKDA 9 (1886): 14662; A. Bulgakov, "Ideal obshchestvennoi zhizni po opredeleniiu katolicheskogo, reformatskogo i luteranskogo veroispovedanii [The Ideal of Social Life by Definition of the Catholic, Reformed, and Lutheran Faiths]," TKDA 9 (1891): 86-102; N. Makkaveiskii, "Vopros o prigotovlenii k pastorstvu v sovremennoi protestantskoi Germanii [The Issue of Preparation for Pastorship in Contemporary Protestant Germany]," TKDA 4 (1894): 536-53; V. Pevnitskii, “Ob otnoshenii k Tserkvi nashego obrazovannogo obshchestva (Publichnoe chtenie) [On the Attitude Towards the Church in Our Educated Society (Public Readings)]," TKDA 2 (1902): 235-68. V. P. Rybinskii, "Bibliia dlia detei [The Bible for Children]," TKDA 1 (1897): 3-34; V. P. Rybinskii, "O Biblii (Publichnoe chtenie) [On the Bible: Public Readings]," TKDA 3 (1902): 359-82.

8 D. I. Bogdashevskii, "Evangelie kak osnova zhizni (po povodu sovremennykh sotsialnoekonomicheskikh voprosov) [The Gospel as the Basis of Life (On Contemporary SocioEconomic Issues)]," TKDA 4 (1906): 547-76; D. I. Bogdashevskii, “Sovremennye vragi Kresta Khristova [Modern Enemies of the Cross of Christ]," TKDA 10 (1908): 273-85; A. A. Glagolev, "Neprekhodiaschee znachenie Vetkhogo Zaveta. Bibliologicheskaia zametka na: Die bleibende Bedeutung des Alten Testaments, von Emil Kautzsch, Tübingen und Leipzig [The Lasting Importance of the Old Testament. Bibliological Article on: Die bleibende Bedeutung des Alten Testaments, von Emil Kautzsch, Tübingen und Leipzig]," TKDA 11 (1902): 491-504; A. A. Glagolev, "Vetkhii Zavet i yego neprekhodiaschee znachenie v khristianskoi Tserkvi [The Old Testament and Its Lasting Importance for the Christian Church]," TKDA 11 (1909): 353-80; 12 (1909): 517-5o. 
of bibliographic notes and reviews, which remain insufficiently studied, have become very important for our area of research. ${ }^{9}$ This genre seems to be heuristically valuable and relevant with respect to the given topic of research. After all, it determined the frontier of the contacts between the national and European intellectual traditions. It demonstrated the degree to which Kyiv researchers were involved in European and global academic, theological, socio-political, moral, and ethical thought. It exposed a critical reflection of foreign experience in raising and addressing vital academic, moral,

Kh. M. Orda, “Apologeticheskaia i polemicheskaia literatura na Zapade protiv sochineniia Ernesta Renana 'Vie de Jesus' [Apologetic and Polemic Literature in the West Versus Ernest Renan's Vie de Jesus ]," TKDA 9 (1864): 71-16o; Kh. M. Orda, “Obozrenie inostrannoi dukhovnoi literatury [Review of Foreign Spiritual Literature]," TKDA 10 (1864): 237-6o; S. M. Solskii, "Bibliograficheskie zametki: 'Prorok Daniil i Apokalipsis sv. Ioanna.' Sochinenie Oberlena, perevod prot. A. Romanova. Tula. 1882 [Bibliographical Notes: 'The Prophet Daniel and the Apocalypse of St. John.' Text by Oberlen, translated by Prot. A. Romanov. Tula, 1882]," TKDA 6 (1883): 356-68; S. M. Solskii, “Bibliograficheskie zametki: 'Zhizn Iisusa Khrista' Edmonda Pressane. Chast 2. SPb., 1883 [Bibliographical Notes: Edmond Pressane's 'Life of Jesus Christ.' Part 2. St. Petersburg, 1883]," TKDA 12 (1884): 539-58; S. M. Solskii, "Bibliograficheskie zametki: 'Zhizn i Trudy sviatogo apostola Pavla' Farrara [Bibliographical Notes: Farrar's 'Life and Works of St. Paul the Apostle']," TKDA 1 (1887):140-52; A. S. Tsarevskii, "Bibleiskaia literatura istekshego 1882 goda na zapade. Vetkhii Zavet [Biblical Literature of 1882 in the West. Old Testament]," TKDA 9 (1883): 109-22; A. S. Tsarevskii, "Bibleiskaia literatura istekshego 1882 goda na zapade. Novyi Zavet [Biblical Literature of 1882 in the West. New Testament]," TKDA 12 (1883): 685-700; A. S. Tsarevskii, "Bibleiskaia literatura istekshego 1883 goda na zapade. Vetkhii Zavet [Biblical Literature of 1883 in the West. Old Testament]," TKDA 5 (1884): 103-23; A. S. Tsarevskii, "Bibleiskaia literatura istekshego 1883 goda na zapade. Novyi Zavet [Biblical Literature of 1883 in the West. New Testament]," TKDA 12 (1884): 559-86; A. S. Tsarevskii, "Bibleiskaia literatura istekshego 1886 goda na zapade. Vetkhii Zavet [Biblical Literature of 1886 in the West. Old Testament]," TKDA 12 (1886): 675-712; A. S. Tsarevskii, "Bibleiskaia literatura istekshego 1886 goda na zapade. Novyi Zavet [Biblical Literature of 1886 in the West. New Testament]," TKDA 3 (1887): 425-57; V. P. Rybinskii, “Zametki o literature po Sv. Pisaniiu Vetkhogo Zaveta za 1904 god [Notes on the Literature on the Holy Scriptures of the Old Testament, 1904]," TKDA 5 (1905): 124-46; 11 (1905): 413-35; D. I. Bogdashevskii, "Bibliografiia: G. S. Chamberlen 'Yavlenie Khrista,' perev. s nem., izd. tretie, SPb, 1907; I. Sazerlend, Sviashchennye knigi Vetkhogo i Novogo Zaveta. Ikh proiskhozhdenie, razvitie i kharakter, S. Pb., 1907; Ernest Renan, Zhizn Iisusa; Ad. Garnak, Sushchnost khristianstva, perev. s nem., Moskva, 19o6," TKDA 10 (1908): 139-55; D. I. Bogdashevskii, “Bibliografia: O. Pfleiderer. Vozniknovenie khristianstva. Perevod G. F. Lvovicha. S-Peterburg, 1910, 175 str.; Adolf Deissmann. Licht vom Osten. Das Neue Testament und die neuentdeckten Texte der Hellenistisch-römischen Welt. Tübingen 1909. I+IX+376," TKDA 2 (1911): 290-98; A. A. Glagolev, "Novosti nemetskoi literatury po bibleiskoi arkheologii [News in German Literature on Biblical Archeology]," TKDA 11 (1901): 466-74; 12 (1901): 610-18. 
and socio-political issues, and evaluated the relevance of such experience for domestic use, reflection that evolved chronologically for the first time and almost synchronously.

From time to time issues related to Biblical studies in Europe and the world, as well as considerations and solutions prompted by these issues, were useful for the research and public practices in which academic scholars of the Kyiv Theological Academy were involved. We will therefore attempt to structure the judgments and ideas generated by the above Kyiv authors, which were based on the comparison of foreign and domestic experience related to the broad social use of Biblical knowledge.

\section{The History of the Orthodox Reception of the Bible: Pursuit of Self Identity in the European Biblical World}

In his research works mentioned above, Prof. Solskyi was probably the first among Kyiv academic researchers of the second half of the nineteenth century to reproduce a wide panorama of historical forms in which the Bible was assimilated by Ukrainian Orthodox culture. In effect, he laid the foundations of the academic history of Biblical studies in Ukraine. Solskyi believed that the assimilation and broad social use of the Bible were signs of a common Christian identity and a marker of affiliation with the global civilized community. The Christian identity has developed through the assimilation of the Biblical worldview, Biblical cultural and symbolic codes, and moral and legal norms that determined the life behavior of our ancestors.

The Bible was viewed as a pan-European heritage. Its reception and inculturation was accompanied by dynamic contacts with European culture, in particular, with the traditions of translating the Bible into European languages. ${ }^{10}$ The cultural components of the Biblical world, according to Solskiy, were formed from the first centuries of the Christian era. The Church Slavonic text of the Holy Scriptures, utilized by the Orthodox in the Ukrainian lands from its origins (the Greek edition by Lucian Antiochus) was the result of complex intercultural interaction of the regional Christian centers (Egyptian Alexandria, Antioch, and Constantinople) and the fruit of the work of their prominent representatives. The language of the Church Slavonic Bible was also often comprised of fused inter-Slavic (Southern and Eastern Slavic) linguistic products. ${ }^{11}$

For centuries after the initial Christianization of Rus' our ancestors were in pursuit of their own identity within the Biblical world. This complex process was twofold. On the one hand, first steps were taken to integrate into European religious space and to undertake the European modernization of culture and lifestyle. Thus, the Bible became one of the fundamental texts of the new education system, helping to "become closer and better informed of Christian literature from abroad." Local scholars translated and interpreted Church Slavonic Biblical texts because they needed to maintain church education and study in their own cultural environment. On the other hand, the national linguistic adaptation of Church Slavonic Biblical and commentary literature occurred

10 Solskii, "Upotreblenie i izuchenie Biblii v Rossii ot krescheniia Rusi," 27.10 (1868): 146-47, 153-54. 
as "an attempt to make the language of the Holy Scripture clearer, and to clarify the perception of its intrinsic meaning." 12

The initial forms of the assimilation of the Biblical text took forms of the adaptation of Biblical books for a better understanding of their content by a broad strata of the people, development of Biblical commentary (through translations and compilations of foreign examples), and the production of special adaptations intended for home use in religious and moral education and family upbringing. Parts of the Bible such as the Gospel, Apostles, Psalter, and Prophetologion acquired special status in society due to their great significance for the Orthodox liturgy and because of their significant moral and educational potential. Finally, the importance of properly read and interpreted Biblical texts, useful for debates with the adherents of other faiths, was increased.13 Thus, in addition to the liturgical, moral, and educational roles of the Bible, its role as an instrument of inter-religious interaction in the old Ukrainian lands also increased.

The primary education of our ancestors, based on the use of the Bible, was fostered by constant contacts with the rest of the Biblical world. In particular, close ties with the Greek (Constantinople) Church supported domestic religious enlightenment. It was especially important in critical periods of foreign invasions of old Ukrainian lands, when in the midst of the stagnation of the local culture "the scribes of those times, the zealots of enlightenment worked mainly in remote Greek monasteries." 14 Thus, European cultural and religious space in times of crisis provided an opportunity to preserve Orthodox Biblical scholarship in the old Ukrainian lands. At the same time, the preservation of the normative Biblical textus receptus by the efforts of the Constantinople Church and its transfer into neighboring territories made it possible not only to strengthen church education and book learning in Orthodox Moldova and Walachia, but also to increase the cultural significance of the old Ukrainian lands with Kyiv as their center. ${ }^{15}$

The cultural potential accumulated in the lands of Kyivav Rus was revealed later, after the 15th century, in other political configurations and within various forms of statehood. However, staying within a single European cultural and intellectual dimension remained as the condition of keeping the unity of the Biblical world. For instance, the first preserved and intensively applied complete Church Slavic version of the Holy Scriptures was produced in Nizhnii Novgorod, which in the first half of the 15th century was in association with the Northern European Hansa and had intensive political and trade relations with the rest of Europe, particularly with the neighboring Polish-Lithuanian Commonwealth (Rzecz Pospolita). This version (the so-called Gennady's Bible) came about as a result of unique and sometimes unprecedented interconfessional cooperation of the Orthodox, Catholics and Jews. In addition to the then

\footnotetext{
12 Solskii, “Upotreblenie i izuchenie Biblii v Rossii ot krescheniia Rusi," 27.10 (1868): 166-70.

13 Solskii, “Upotreblenie i izuchenie Biblii v Rossii ot krescheniia Rusi," 27.10 (1868): 175-76.

14 Solskii, "Upotreblenie i izuchenie Biblii v Rossii ot krescheniia Rusi," 27.10 (1868): 176-80; 27.11 (1868): 260.

15 Solskii, “Upotreblenie i izuchenie Biblii v Rossii ot krescheniia Rusi," 27.11 (1868): 263-65.
} 
known and accessible Church Slavic manuscript copies, the compilers of the Genady's Bible used the European experience of compiling German and Latin Biblical editions, in particular, the inner composition of these editions. They tried to use "all the best they could find in the Western printed Bibles." 16

The old Ukrainian (and the old Belarusian) lands had a specific destiny. In the late $15^{\text {th }}$ and early 16 th centuries they became part of the Grand Duchy of Lithuania and later part of Rzecz Pospolita, our ancestors were thereby included in the "general life cycle of Western nations." This facilitated gradual integration into the European educational system (in particular, the Universities of Krakow and Prague), more intensive relations with the Western Slavic lands, familiarization with printing in those countries, and the development of domestic printing capabilities. The Biblia Ruska compiled by the Belarusian Francisk Skoryna, originally published in Prague, became symbolic in this context. It was a translation born on the crossroads of cultures: Church Slavonic, Czech (Hussite), German, and Latin. Such outstanding works of old Ukrainian and old Belarusian Biblical literature as Peresopnytsia Gospel, Krekhiv Apostle, NT translations by Vasyl Tiapynskyi and Valentyn Negalevskyi, written specifically in the language spoken by the people, and most importantly the first printed Church Slavonic Bible, known as the Ostroh Bible, were produced specifically on the Ukrainian lands.

The compilers of the Ostroh Bible used one of the copies of the Gennady's Bible as a base. (It was considered at the time to be a Cyril-and-Methodius translation from the Septuagint, inherited from the time of Volodymyr the Great.) Prior to this edition, elements of European editions, in particular, the Vulgate, had alredy been integrated. The text of the Ostroh edition was compared to then available Church Slavonic versions as well as to West Slavic Biblical translations, in particular to the Czech ones. ${ }^{17}$ This edition reflected trends revealed by Western Biblical culture in the late 16 th century. These trends included new opportunities in disseminating the Bible through printing and bookselling, a view of the Bible as not only a church tool but also a "national heritage," and seeds of critical analysis based on academic criteria. ${ }^{18}$ These pan-European motives were combined with local needs: "the need to satisfy religious curiosity," the need for "instruction and precepts of piety," and the need to use new arguments in religious debates with adherents of other faiths. ${ }^{19}$ The Ostroh Bible became a sign of yet another modernization of local Orthodox culture through intercultural and inter-confessional interaction. This is how a new, early-modern panEuropean Biblical world began to emerge.

In addition, subsequent improvements made to the Church Slavonic text of the Holy Scripture in the 18th century, predominantly by graduates of the Kyiv-Mohyla theological and philological school, constantly correlated with foreign experience, the experience of the larger Biblical world. These trends included the desire to achieve the

16 Solskii, “Obozrenie trudov po izucheniiu Biblii v Rossii s 15 veka,” 1.2 (1869): 195-201.

17 Solskii, "Obozrenie trudov po izucheniiu Biblii v Rossii s 15 veka," 1.2 (1869): 212-2O.

18 Solskii, “Ostrozhskaia Bibliia," 296-97.

19 Solskii, "Ostrozhskaia Bibliia," 300, 303-04, 307. 
same level and scale in translating and publishing the Bible as in the West, the use of European Biblical editions published in their original languages (primarily so-called polyglot publications) in textual studies, and the referencing of Western commentators. ${ }^{20}$ Greek-Latin education, based on the study of ancient languages including the original languages of the Bible, became the foundation for quality learning and the study of the Holy Scriptures. It also established a general European standard for theological schooling, which became crucial for church educational reform and the development of large scale religious education in the nineteenth century. ${ }^{21}$

The most significant attempt to integrate the Orthodox world into the global Biblical dimension was made in the early nineteenth century. A trend experienced by Europe during the Reformation and by Ukrainian culture in the 16th century as part of Rzecz Pospolita was then initiated in the Russian Empire, which included the Ukrainian lands. It was an attempt to introduce the Bible, translated into national languages (primarily Russian), across the country. The attempt was linked to the initiatives of Emperor Alexander I and the activity of the Russian Bible Society.22

Setting up Bible Societies in an Orthodox state became a distinct indication of attempts to promote cultural modernization based on the Western European model. Thus, it was not by coincidence that the Bible was at the focus of such modernization: "when the Western nations strengthened their Christian religious mentality, when in the times of the Reformation they enriched themselves with national translations of Biblical books, made from the original texts..., under this favorable influence, they created an entire culture." ${ }^{23}$ The inculturation of the Bible according to the Western model also objectively opened the opportunity for the incorporation of Western patterns of religious and socio-political culture developed in Europe under the influence of Biblical norms and guidelines.

As an unchanging common religious symbol and a marker of pan-European identity, the Bible appeared to be a powerful ideological factor for the socio-political and even economic life of the time. In addition to the traditional moral and educational influence within church walls and the family, the spread of Biblical teachings became a means of reducing social and class tension in society. "The rapid expansion of Biblical Societies was conditioned by the reaction to the French Revolution and the Napoleonic aftermath..., the desire of the most influential classes in society to seek salvation in maintaining and disseminating religious beliefs." The Russian empire "did not stand aloof from these ideas." It was clear that the aforementioned classes "could not ignore such a vast Christian monarchy as Russia." ${ }^{24}$ Indeed, as it turned out later, virtually all

Solskii, “Obozrenie trudov po izucheniiu Biblii v Rossii s 15 veka," 1.4 (1869): 546-47, 556-58.

Solskii, "Obozrenie trudov po izucheniiu Biblii v Rossii s 15 veka," 1.4 (1869): 576-77.

Solskii, "Obozrenie trudov po izucheniiu Biblii v Rossii s 15 veka," 1.6 (1869): 8o1-02.

Solskii, "Ob uchastii imperatora Aleksandra I," $172-73$.

Solskii, "Ob uchastii imperatora Aleksandra I," 173-75. 
ruling strata of Russian society in the early 19th century "fully shared the reactionary views of the privileged Western classes." 25

Solskyi was the first in local Bible studies to attempt to single out and undertake a systematic analysis of the key areas of social integration of the Bible, not only as a religious or moral and educational tool but also as an important ideological factor in the socio-political development of a Christianized society. In addition to traditional means of religious education and moral upbringing, he underlined the following: active philanthropy to attract broad popular strata to religious education; consequently, cheaper and free distribution to maximize popularity among the poorest strata; dissemination of the Bible in national languages to integrate "aliens" (national minorities); development of a system of general popular education and enlightenment on the basis of Biblical studies, and the publication of "popular religious literature" to facilitate these goals. ${ }^{26}$

Most important is that the ideological message was articulated in various ways, aiming to shape a certain type of nation-wide civil inter-strata unity that would typologically be consistent with the concept of the so-called Imperial nation. The Bible, specifically its Russian translation, was to become the core of the local version of the civil religion. Thus, it was no coincidence that the Bible was promoted "for general use by the people," "for reading by people of any strata," and attempts were made to make the Bible "a popular, civil book." ${ }^{27}$ A systemic ideal was fostered, which advanced the all-strata, supra-class religious enlightenment of the people through the integration of the Bible into national culture. At the same time, European models were to be used, primarily in the translation and dissemination of the text itself, and in organizing Biblical education. ${ }^{28}$ Accordingly, important ideological, moral and institutional benefits were underscored, which would strengthen society through the dissemination of the Bible: religious conversion, education and enlightenment of national minorities; a nationwide "spiritual union" that would "strengthen the most distant parts of the state," and "the rise of the national spirit based on moral foundations." 29

One should not overestimate the "European nature" of the planned ideological and cultural modernization. Political customs of the absolute monarchy determined the entirely archaic necessity in having "monarchical rule" as "the highest authority that legally endorses any cause and gives it the greatest national significance." Accordingly, it was evidenced by the fact that financial support by the emperor was decisive. ${ }^{30}$ Finally, the archaic features of the then society in the Russian Empire did not contribute to such modernization attempts. Many factors slowed down the declared measures: clergy, "rigid with their routine habits"; society that turned out to be "unprepared to

\footnotetext{
25 Solskii, "Ob uchastii imperatora Aleksandra I," 188.

26 Solskii, "Ob uchastii imperatora Aleksandra I," 176-77, 181-82, 187.

27 Solskii, "Ob uchastii imperatora Aleksandra I," 178, 180.

28 Solskii, "Ob uchastii imperatora Aleksandra I," 183-84.

29 Solskii, "Ob uchastii imperatora Aleksandra I," 190.

Solskii, "Ob uchastii imperatora Aleksandra I," 18o-82.
} 
consciously accept the need to develop a new cause;" distrust of "Westernization" and "foreign innovations hostile to Orthodox life;" fear that "dissemination of the Bible is the most reliable way to a new Reformation, and the spread of Biblical translations is a way to multiply sects and schisms." 31

Concerns regarding "disintegration risks" inherent in the adoption of the European experience of social assimilation of the Bible also accompanied later attempts to modernize the spiritual and cultural life of the Russian Empire. At the same time, new productive ideas were expressed and generated by foreign experience. The "West" often turned into a very true mirror of "domestic" reality. Below, we will trace the reflections of a number of Kyiv authors whose works were not based on historical retrospectives, but on the examination of actual Western experience.

\section{The Bible and the Social Ideal: The Consistency of Biblical Ideas and Meanings With the Vital Needs of European Society}

Professor Solskyi's study of historical experience related to cultural implementation of the Bible in a broad European context in the mid 186os was clearly not a random coincidence. As we know, it was a time when new attempts were undertaken to promote European modernization in the Russian Empire. As always, these attempts were initiated "from above" by the ruling elite, and it was necessary to examine the previous experience of modernization. Thus, the great attention paid by Solskyi to Biblical reforms of the Mohyla period and the beginning of the 19th century was quite consistent with the hopes inspired by new opportunities for the inculturation of the Bible among the broad national strata in the 186os.

At that time, work on the Russian Synodical translation of the Bible was gaining momentum and, in line with the ideas and considerations of the period of rule of Alexander I, it was seen as a driver of social integration, the development of general civil ideology, of the system of education and enlightenment, and, finally, an ideological factor of modernization according to the European model. The Bible, in its universal version, was supposed to become a platform for such religious enlightenment teaching "to honor the Church of God, the sole rule of the Tsar, the respect of parents, and subordination to superiors." Such outcomes would have been a perfect embodiment of the social model that had long been implemented in the West. ${ }^{32}$ Other Kyiv authors of those years also pointed to the importance of utilizing European experience in disseminating Biblical knowledge for the purpose of overcoming "social alienation from the Church." 33

As it was seen, especially in the example of the German states of the 18th-19th centuries, the issue of Biblical education, particularly at the school level, gained broad public significance, state authorities viewing it as of strategic importance for the

Solskii, "Ob uchastii imperatora Aleksandra I," 191, 194.

32 Solskii, “Tserkovno-prikhodskaia shkola," 154-55, 160.

Voronov, "Zametki iz tserkovnoi zhizni Zapada," 252. 
education of citizens. Furthermore, the Bible, as a source of knowledge, was able to bring together family and school in their common educational impact on the younger generation. ${ }^{34}$

At the same time, Kyiv researchers did not fail to recognize that, along with the Bible's church use in the West it was increasingly used in secular civic education. Such education could include the "propaganda of general non-confessional religion's," appeal to reason as an "ultimate measure," as well as rationalized and entirely capitalist ways of disseminating Biblical knowledge among the masses based on sociological information about the structure of society and the psychology of age perception..$^{35}$

The Western secular model of Bible assimilation and use was criticized as "undermining the historical foundations of Christianity, rejecting the authenticity and reliability of its original sources." 36 Educational and cultural secularism was criticized as an alien phenomenon, allegedly brought from the West by "foreign teachers and educators of our noble youth." ${ }^{37}$ Thus it was not surprising that a moderate pro-Western perspective on this issue went hand in hand with a reactionary and defensive one as early as the 188 os. The keynote to such a reaction was a call to strengthen the "local," "grass-roots" pursuit of "own way," "independent national development, free from unconditional admiration for Western European life." ${ }^{38}$ However, the pursuit of an "own way" in combination with attempts to adopt foreign experience acquire meaning only where the desired ideal models of social life establish themselves with the help of the Bible in various areas. Thus, it was very important for Kyiv academic researchers to examine European examples of how the Bible was used to develop such ideal models.

In the history of post-Reformation Europe, mainly in the Protestant countries, the Bible played the role of the "theocratic constitution" of some sort, a basis for an entire system of social, political, civil, and moral arrangements and agreements. "Obedience to God's Will on Earth must express itself in obedience to God's Law as revealed and given to man in the books of the Holy Scripture... so that the external order of social life becomes the fulfillment of God's Law." 39 A view of the Bible as a civil "constitution" sometimes played a revolutionary and humanizing role. ${ }^{40}$ At times, this role was modernizing, cultural, at least in the forms of theological liberalism, when Biblical knowledge (such as "examples taken from Biblical history") became the basis for establishing "general moral education, completely free of denominational coloring," in the public schools. ${ }^{41}$

34 Rybinskii, "Bibliia dlia detei," $3-5$.

35 Rybinskii, "Bibliia dlia detei," 9-10, 14, 18, 21, 23, 29-30.

36 Bogdashevskii, "Sovremennye vragi Kresta Khristova," 275.

37 Pevnitskii, "Ob otnoshenii k Tserkvi," 255-58.

38 Drozdov, "Zaprosy sovremennoi zhizni," 212-15.

39 Bulgakov, "Ideal obshchestvennoi zhizni," 91.

40 A. Bulgakov, "Chetyriokhsotletie Novoi istorii [The Fourth Century of the New History]," TKDA 9 (1893): 106-07. 
An important aspect of European experience, noted by Kyiv researchers, was the emphasis on the practical side of Biblical instruction provided to future theologians and pastors. The use of the Bible in their professional work was not supposed to be limited to the church; it was expected to also take place in the public schools as well as in private home education and upbringing. Such experience contrasted with the habits of Orthodox religious schooling and upbringing, prevalently "non-instructional" in its nature..$^{42}$ Finally, they emphasized the benefits of European experience in maximizing the popularity of Bible-based education with the aim of inculcating general civil virtues of "religiosity" and "nationality." 43

In the early 19oos, especially during the years of very disturbing but also inspired revolutionary events, an important problem was raised: how socially and politically relevant can a Biblical ideal be? How Biblical patterns of moral choice and obedience to theocratic authorities can be applied in personal life (private, everyday) or public life (civic, political, economic, and cultural)? At the beginning of the 20 th century, Kyiv academic scholars, who studied the worldwide and European experience of the religious and secular perception of the global progress of capitalism and related issues, were convinced that the vulgar use of the Biblical moral and social ideal in socialist and revolutionary rhetoric was largely harmful.

It was extremely important to come up with appropriate forms for the expression of the "Evangelic foundation of life," free from "distortions," and from "the use of the Gospel in a form that is clearly inconsistent with its substance." Without denying the applicability of the Biblical ideal "in the state, society, science, art, etc.," at the same time, one should avoid trying to "trivialize or prune down the Gospel." After all, "we don't intend to boil the Gospel down to mere sociology and convert Evangelical perfection into simple social formulas." Biblical preaching is primarily religious and not social; it "does not promote any social theory." The only proper outcome of the adequate social assimilation of Biblical knowledge is spiritual rebirth and individual transformation." ${ }^{4}$

Biblical interpretations were also used in the ideology and political life of the early 2 oth century. In a rather exotic way, such interpretations were utilized to justify certain political projects, both on the global level and in the Russian Empire. For instance, aspirations for political emancipation and the desire to "achieve Jewish equality in Russia" in that period were accompanied by rather controversial appeals to the Bible and its Kabbalistic interpretations. Such interpretations reflected "recent internal political life." 45 Also, the Bible was used to ideologically justify the global Zionist project. Despite the religious indifference of the vast majority of Zionists, especially those of Western

42 Makkaveiskii, "Vopros o prigotovlenii k pastorstvu," $543-53$.

43 N. Makkaveiskii, "Religiia i narodnost kak osnova vospitaniia [Religion and Nationality as the Basis of Education]," TKDA 11 (1895): 444-48.

44 Bogdashevskii, "Evangelie kak osnova zhizni," 547-49, 556, 565-68.

45 A. A. Glagolev, "Mnimoe prorochestvo Vetkhogo Zaveta o Rossiiskoi Gosudarstvennoi Dume [The Imaginary Prophecy of the Old Testament on the Russian State Duma]," TKDA 12 (1905): 661-62. 
origin, a rather unique ideological conflict emerged at that time, when an entirely modern political national ideology became preoccupied with archaic sacral arguments. On the one hand, "only religion and worship support the living aspiration for Zion in the Jews," but on the other hand, it was the Bible that emerged as a meaningful basis for various Zionist movements: "both trends, the cultural one and religious one, have one common source - the Bible as a sacred monument not only for Jews, but for all Mankind." 46

According to the Kyiv academic researchers, religious preaching of the Biblical moral and ethical ideal, and Biblical instructions promoting civil peace as well as collective and individual well-being were the most productive ways of using Biblical knowledge to understand and address vital issues of contemporary society. Proven on a large scale in Europe and North America, this way had shown that the Bible is capable of being "a source of culture and the basis of well-being," and "all issues related to the Bible are considered to be issues for the whole nation and country." A productive development of patterns for such a perception of the Bible, as a cultural and creative factor of social development, may take various institutional shapes, such as family communications; use of the Bible in school education; use of Biblical images and symbols in private routine contacts, public speaking and political rhetoric, and the creative interpretation of Biblical plots, images, and symbols in Literature and Art. ${ }^{47}$

The direct implementation of such Western experience was hindered by several key factors: the religious indifference of the so-called "educated class"; false understanding of religiosity as an "uncertain feeling" that does not require indoctrination and explanations; loss of confidence in the Bible because of its obvious inconsistency with the then prevailing positive science, and anti-religious propaganda as a component of socialist movements. Thus, the need to properly evaluate the true specific nature of religious and moral guidance as well as scientific knowledge, and establish "reasonable religiosity" coupled with "critical thinking" were on this basis proclaimed as important educational and enlightenment tasks. This is how the external experience of other European nations in developing the symbolic Biblical world were rooted in Ukraine. At the same time, apologetic goals of Church tradition could also be implemented: "learn the Law of the Lord day and night," and ensure the "special guidance" of the Church as "the best interpreter of the meaning and spirit of the Bible." 48

46 A. A. Glagolev, "Sionistskoe dvizhenie v sovremennom yevreistve i otnoshenie etogo dvizheniia k vsemirno-istoricheskoi zadache bibleiskogo Izrailia [The Zionist Movement in Modern Judaism and the Relation of this Movement to the Global Historical Objective of Biblical Israel]," TKDA 4 (1905): 561-63. 


\section{The Frontier of Intellectual Contact with the Biblical World: Anticipating the Rise of Modern Global Strategies}

As we have already noted, the legacy of the Kyiv Theological Academy professors comprises a rather broad and completely unexplored corpus of bibliographic notes and reviews of foreign academic and theological works. At the time, this genre of writing became a real frontier for contact between local and the World intellectual traditions. This genre provided an extremely prompt critical reflection of the foreign ways of raising and addressing vital academic, moral, social, and political objectives. It reviewed the relevance of foreign experience and its suitability for domestic use. It thus demonstrated the degree to which the Kyiv academic scholars were engaged in European and Global scientific, theological, socio-political, and moral-ethical thought. It discovered the world tradition of reading and using the Bible, interpreted its meanings, symbols, and precepts in various areas of culture and in various spheres of public life.

In addition, we have discussed above the collision of the modernizing and the reactionary, and defensive trends in the social application of the Bible within European culture. Especially during the 19th and early 2oth centuries, this development was associated with the transformation of the public dimension of the perception and assimilation of the Biblical text. The traditional dimension of liturgical, preaching, and moral practices, which also partially covered family life, were gradually secularized in Europe. It was less important than both the common civil dimension (universal, national) and the private, personal dimension, which was undergoing development. All of this substantively transformed the very idea and practical objectives of popularizing the Bible. From the beginning of the 186os, a "new period" in European Biblical Enlightenment began, which was supposed to overcome the "pathological developments of time," including religious indifference and anti-religious propaganda. ${ }^{49}$

In this connection, the concepts of "nationality," "popularity," "universal accessibility," and "universal use" of the Bible were reconsidered in Europe. This rethinking was closely linked to the awareness of the need for Biblical justification of moral and philosophical principles debated in society. ${ }^{50}$ The idea was cultivated in a combination of academic and theological content in the popular interpretation of Biblical knowledge able to lift the public above routine mental stereotypes, and "satisfy the demands of people with academic education," 51 which would be aimed at "not only teaching and touching emotions, but also delivering truly academic knowledge." 52

The public cultural and religious dimension was renewed, and the private dimension in the transmission of Biblical knowledge had emerged through blending of traditional ecclesiastical "practically instructive exegetics" with special literature

49 Orda, "Obozrenie inostrannoi dukhovnoi literatury," 243-45, 251-52.

$5^{\circ} \quad$ Tsarevskii, "Bibleiskaia literatura istekshego 1882 goda na zapade. Vetkhii Zavet," 685.

51 Solskii, "Bibliograficheskie zametki: 'Zhizn i Trudy sviatogo apostola Pavla' Farrara," 141.

$5^{2}$ Rybinskii, "Zametki o literature po Sv. Pisaniiu," 413. 
designated separately for secondary schools, separately for universities, and separately for private self-education. ${ }^{53}$

Biblical knowledge, in somewhat unexpected forms, was used in the transformation and modernization of the global picture of the World. For instance, the traditions of seemingly abandoned archaic "synoptic" discourse began to emerge quite exotically at the end of the 19th century. Biblical prototypes were frequently used to interpret socio-political developments, develop some sort of "pan-European (and even global) historiosophy," when "clear signs of Prophetic predictions" were seen "in the present state of human societies, in modern communist and socialist movements, and in the entire direction of modern civilization in general." ${ }^{54}$

Another manifestation of the picture of world modernization on a Biblical basis was the use of Biblical knowledge by Europeans as a basis for social debate of not only moral or social issues (as mentioned above), but also issues of legal, political, and economic nature. For instance, Biblical Archeology became an unconventional source for discussing issues related to the genesis of criminal law and legal consciousness in general, socio-ethical aspects of economic relations, in particular property relations, social evil and social justice, as well as political and economic aspects of individual freedom. ${ }^{55}$ The Biblical narrative was consistent with the ideas of social reformation that were quite relevant at the end of the 19th and early 2 oth centuries both for Western Europe and the Russian Empire. ${ }^{56}$

The modern transformation of the cultural dimension, as evidenced by Western publications and critically evaluated by the Kyiv researchers, had another consequence that was important for further religious evolution of the modern world. What we refer to is the use of Biblical material for pan-European or Global projects aiming to develop a modernized universalistic religion: "introducing a democratic popular world church" 57; creating a universalistic "supernatural religion" 58 based on "moral, subjective faith." ${ }^{99}$ Such projects were quite organically interlaced with the rationalist appeal to deny the religious and cultural exclusiveness of the Bible, to view it as one of the developments in the history of world culture, and to put it on a par with the fundamental texts of other religions. ${ }^{60}$ The new religious comparativism, developed on the basis this approach, studied the genesis of the Bible and demonstrated unconventional

Tsarevskii, "Bibleiskaia literatura istekshego 1883 goda na zapade. Vetkhii Zavet," 123; Tsarevskii, "Bibleiskaia literatura istekshego 1886 goda na zapade. Vetkhii Zavet," 676, 711.

Solskii, "Bibliograficheskie zametki: 'Prorok Daniil i Apokalipsis sv. Ioanna.' Sochinenie Oberlena," 364 .

Glagolev, "Novosti nemetskoi literatury po bibleiskoi arkheologii," 467, 470-71, 473-74.

Bogdashevskii, "Bibliografia: Ernest Renan. Zhizn Iisusa," 15 o.

Orda, "Obozrenie inostrannoi dukhovnoi literatury," 243.

Tsarevskii, "Bibleiskaia literatura istekshego 1886 goda na zapade. Vetkhii Zavet," 430-31.

Solskii, “Bibliograficheskie zametki: 'Zhizn i Trudy sviatogo apostola Pavla' Farrara," 143-44.

Bogdashevskii, "Bibliografiia: I. Sazerlend. Svyashchennye knigi Vetkhogo i Novogo Zaveta," $142-43$. 
forms of intercultural and inter-confessional interaction. For instance, some Western scholars have researched a possible influence of the Eastern traditions (in particular Buddhism) on the development of the New Testament text and the early Christianity in general. ${ }^{61}$

However, for those Kyiv thinkers who were Orthodox apologists, the emergence of new powerful channels for the translation of Biblical experiences into society was no less dangerous than the foreign quest for a "new global religion." Although these channels originated in the West on the basis of theological liberalism and philosophical and scientific rationalism, they were also determined by certain domestic circumstances. In the West, Biblical content and knowledge about the Bible were increasingly disseminated through the channels of secular culture. The out-of-church reading and interpretation of the Biblical text enabled the emergence of unofficial and often nontheological Biblical studies based on a rationalist criticism of the Bible. Although this transformation of the public dimension in the area of reading and assimilation of the Bible began in Europe, it gradually became an indicator of "maturity" of Ukrainian society at the beginning of the 2 oth century. ${ }^{62}$

\section{Conclusion}

A regular and powerful appeal of the Kyiv authors to foreign experience and its analysis and comparison with local spiritual, ideological, cultural and political circumstances were predicated by very close contacts of the local theological tradition with the West. Such contacts began to develop back at the time of the Kyiv-Mohyla Academy and became even more intensive during the period of the KTA. An increasingly obvious demand for world experience and examples clearly demonstrated the polyphonic unity of the European world, including its spiritual-cultural component, the normative and symbolic core of which was the Bible. Therefore, the Kyiv researchers were gradually expanding their own footprint in the vast Biblical world by producing both works specifically written on the subject and individual comments scattered through various articles, monographs, reviews, etc.

The Biblical experience, as a field of meanings which provided a prism for the perception of important historical events in Europe and in the Europe-centric world of the 19th and early 2oth centuries took root in quite contradictory ways. The crisis of traditional, thousands of years old forms of assimilation of Biblical values through liturgical and paraliturgical practices, religious education and family moral upbringing led to a broad transformation of the public (civil) dimension in the area of reading and using the Bible.

Biblical subjects, motifs, and symbols began to be used to implement both global and local cultural, religious, and even political projects. In particular, the Bible was

61 Tsarevskii, "Bibleiskaia literatura istekshego 1882 goda na zapade. Vetkhii Zavet,” 686.

62 Bogdashevskii, “O. Pfleiderer. Vozniknovenie khristianstva," 29o-92. 
used as the foundation for the nationwide system of religious education aimed at strengthening civic unity, a European "proto-national" project.

The transformation of the cultural and educational landscape of European countries, primarily due to the growing weight of science and the increasing availability of education to the broad public, also expanded the boundaries of the public dimension in terms of debates on Biblical issues. The Church's monopoly over Biblical educational practices was destroyed by emerging and growing secular Biblical studies. The new ways of assimilating Biblical information increasingly relied on rationalist criticism of church perspectives. Moreover, new Global non-confessional or inter-confessional religious projects were developed. The Bible was used to understand the social, economic, political, and moral issues relevant in the late 19th and early 2 oth centuries, the period of industrial capitalist Modernism.

There was a growing demand and opportunity to utilize the Bible's symbolic language for defining ideas of global (or at least pan-European) unity. Intercultural and inter-confessional interaction emerged as a factor of a regular up-to-date re-reading of the Biblical text and the text of European culture as a whole. The new interpretation of Biblical symbols was congruous with Europe's new place in the Global civilization. This is how the European and simultaneously the global modernization cultural paradigm was taking shape. It became a defining marker of the entire twentieth century, and extended its impact into the beginning of the present century.

By comparing the foreign experience of the assimilation and use of the Bible with the local, domestic situation, the Kyiv academic scholars had objectively reinforced the idea of a universal Biblical world. As a cohesive combination of spiritual, symbolic, ethnic, and geographical origins and elements, in modern terms "a geopolitical phenomenon," the Biblical world was increasingly globalized and modernized. As a result, however, the concept of "proto-Ukrainian" culture and society was challenged. These challenges have become extremely apparent in the first decades of the twentieth century when modern Ukrainian statehood emerged and the Ukrainian nation and culture began to take shape.

Even today, our self-identification as Europeans and full members of the Global Community of Nations urges us to interpret the experience of reading the Bible as a source of meanings shared with the rest of the World and with the experience of other nations. This experience, as we see, has been drawing the attention of Kyiv intellectuals and representatives of the academic community for more than a century and a half. Therefore, we can metaphorically acknowledge the special role of the Kyiv Academy in shaping Ukraine's self-awareness and identity and finding its own place in the symbolic Biblical world.

\section{Bibliography}

Bogdashevskii, D. I. "Bibliografiia: G. S. Chamberlen 'Yavlenie Khrista,' perev. s nem., izd. tretie, SPb, 1907; I. Sazerlend. 'Sviashchennye knigi Vetkhogo i Novogo Zaveta. 
Ikh proiskhozhdenie, razvitie i kharakter.' S. Pb., 1907; Ernest Renan. 'Zhizn Iisusa';

Ad. Garnak 'Sushchnost khristianstva.' Perev. s nem., Moskva, 19o6.” TKDA 9 (1907): $139-55$.

Bogdashevskii, D. I. “Bibliografia: O. Pfleiderer. 'Vozniknovenie khristianstva.'

Perevod G. F. Lvovicha. S-Peterburg, 1910, 175 str.; Adolf Deissmann. 'Licht vom

Osten. Das Neue Testament und die neuentdeckten Texte der Hellenistischrömischen Welt.' Tübingen 1909. I+IX+376." TKDA 2 (1911): 290-98.

Bogdashevskii, D. I. "Evangelie kak osnova zhizni (po povodu sovremennykh sotsialnoekonomicheskikh voprosov) [The Gospel as the Basis of Life (On Contemporary Socio-Economic Issues)]." TKDA 4 (1906): 547-76.

Bogdashevskii, D. I. "Sovremennye vragi Kresta Khristova [Modern Enemies of the Cross of Christ]." TKDA 10 (1908): 273-85.

Bulgakov, A. "Chetyriokhsotletie Novoi istorii [The Fourth Century of the New History]." TKDA 9 (1893): 106-07.

Bulgakov, A. "Ideal obchchestvennoi zhizni po opredeleniiu katolicheskogo, reformatskogo i luteranskogo veroispovedanii [The Ideal of Social Life by Definition of the Catholic, Reformed, and Lutheran Faiths]." TKDA 9 (1891): 86-102.

Bulgakov, A. "Iz zagranichnoi religioznoi zhizni [Foreign Religious Life]." TKDA 10 (1893): 282-92.

Glagolev, A. A. "Mnimoe prorochestvo Vetkhogo Zaveta o Rossiiskoi Gosudarstvennoi Dume [The Imaginary Prophecy of the Old Testament on the Russian State Duma]." TKDA 12 (1905): 66o-63.

Glagolev, A. A. "Neprekhodiaschee znachenie Vetkhogo Zaveta. Bibliologicheskaia zametka na: Die bleibende Bedeutung des Alten Testaments, von Emil Kautzsch, Tübingen und Leipzig [The Lasting Importance of the Old Testament. Bibliological Article on: Die bleibende Bedeutung des Alten Testaments, von Emil Kautzsch, Tübingen und Leipzig]." TKDA 11 (1902): 491-504.

Glagolev, A. A. "Novosti nemetskoi literatury po bibleiskoi arkheologii [News in German Literature on Biblical Archeology]." TKDA 11 (1901): 466-74; 12 (1901): 610-18.

Glagolev, A. A. "Sedmoi vsemirnyi sionistskii kongress v yevreistve [The Seventh World Zionist Congress in Jewry]." TKDA 2 (1906): 328-41.

Glagolev, A. A. "Sionistskoe dvizhenie v sovremennom yevreistve i otnoshenie etogo dvizheniia k vsemirno-istoricheskoi zadache bibleiskogo Izrailia [The Zionist Movement in Modern Judaism and the Relation of this Movement to the Global Historical Objective of Biblical Israel]." TKDA 4 (1905): 513-65.

Glagolev, A. A. "Vetkhii Zavet i yego neprekhodiaschee znachenie v khristianskoi Tserkvi [The Old Testament and Its Lasting Importance for the Christian Church].” TKDA 11 (1909): 353-80; 12 (1909): 517-50.

Golovashchenko, S. I. “Apologeticheskii komponent v rabotakh bibleistov Kievskoi dukhovnoi akademii kontsa 19 - nachala 20 st. (K probleme sopostavleniia bogoslovskogo i nauchnogo diskursov) [The Apologetic Component in the Works of Biblical Scholars of the Kyiv Theological Academy of the Late 19th and Early 
2oth Centuries (Comparing Theological and Academic Discourses)]." Vestnik Pravoslavnogo Sviato-Tikhonovskogo gumanitarnogo universiteta 3.47 (2013): 6o-74. Golovashchenko, Sergiy. "Biblical Studies at the Kyiv Theological Academy (19th Early 2oth Centuries): The Results and Prospects of the Research." Kyiv-Mohyla Humanities Journal 2 (2015): 11-30. Accessed October 5, 2015. DOI:10.18523/ KMHJ51019.2015-2.11-30.

Golovashchenko, S. I. "Bibliia yak predmet populiarnoho vyvchennia: kyivska viziia kintsia 19-pochatku 20 st. (Volodymyr Rybynskyi) [The Bible as a Subject of Popular Study: The Kyivan Vision of the Late 19th and Early 2oth Centuries (Volodymyr Rybinskyi)]." Kyivska Akademiia 8 (2010): 44-50.

Golovashchenko, S. I. Doslidzhennia ta vykladannia Biblii v Kyivskii dukhovnii akademii XIX - pochatkuXX st. [Research and Instruction of the Bible at the Kyiv Theological Academy in the 19th and Early 2oth Centuries]. Kyiv: Vydavnychyi viddil Ukrainskoi Pravoslavnoi Tserkvy, 2012.

Golovashchenko, S. I. "Mizh akademichnym vyvchenniam i misionerskoiu populiaryzatsiieiu Biblii: 'osoblyva dumka' profesora Volodymyra Rybinskoho [Between Academic Study and Missionary Popularization of the Bible: 'The Specific Opinion' of Professor Volodymyr Rybinskyi].” Naukovi zapysky NaUKMA 141 (2013): 23-31.

Golovashchenko, Sergiy. "Orthodox Christian Biblical Studies in Pursuit of Identity: The Role and Impact of Personal Research Practices." Kyiv-Mohyla Humanities Journal 3 (2016): 105-21. Accessed July 28, 2016. DOI:10.18523/kmhj73944.20163.105-121.

Golovashchenko, S. I. "Pravila dlia rukovodstva pri sostavlenii obiasnitelnykh primechanii k russkomu tekstu Biblii Ya. O. Olesnitskogo: peredistoriia rosiiskoi tlumachnoi Biblii [Guidelines for the Preparation of Explanatory Notes to the Russian Text of the Bible by Ya. O. Olesnitskii: Background of the Russian Interpretational Bible]." Naukovi zapysky NaUKMA 50 (2006): 56-63.

Golovashchenko, S. I. "Pro rol 'Mohylianskoi doby' v stanovlenni i rozvytku kyivskoho dukhovno-akademichnoho bibliieznavstva [The Role of the 'Mohyla Era' in the Evolution and Development of Kyiv Theological-Academic Biblical Studies]." TKDA 19 (2013): 100-07.

Gołowaszczenko, Sergij. "Recepcja europejskiej krytyki biblijnej w Akademii Kijowskiej. Wymiar hermeneutyczny a ideologiczny.” ¿ОФIA. Pismo Filozofów Krajów Stowiańskich 7 (2007): 191-200.

Drozdov, N. "Zaprosy sovremennoi zhizni v otnoshenii k bogoslovskoi nauke [The Demands of Modern Life in Relation to Theological Studies]." TKDA 10 (1885): 210-30.

Makkaveiskii, N. "Religiia i narodnost kak osnova vospitaniia [Religion and Nationality as the Basis of Education]." TKDA 11 (1895): 428-72. 
Makkaveiskii, N. "Vopros o prigotovlenii k pastorstvu v sovremennoi protestantskoi Germanii [The Issue of Preparation for Pastorship in Contemporary Protestant Germany]." TKDA 4 (1894): 536-53.

Orda, Kh. M. "Apologeticheskaia i polemicheskaia literatura na Zapade protiv sochineniia Ernesta Renana 'Vie de Jesus' [Apologetic and Polemic Literature in the West Versus Ernest Renan's Vie de Jesus].” TKDA 9 (1864): 71-16o.

Orda, Kh. M. "Obozrenie inostrannoi dukhovnoi literatury [Review of Foreign Spiritual Literature]." TKDA 10 (1864): 237-6o.

Pevnitskii V. "Ob otnoshenii k Tserkvi nashego obrazovannogo obshchestva (Publichnoe chtenie) [On the Attitude Towards the Church in Our Educated Society (Public Readings)]." TKDA 2 (1902): 235-68.

Rybinskii, V. P. "Bibliia dlia detei [The Bible for Children]." TKDA 1 (1897): 3-34.

Rybinskii, V. P. "O Biblii (Publichnoe chtenie) [On the Bible: Public Readings].” TKDA 3 (1902): 359-82.

Rybinskii, V. P. "Zametki o literature po Sv. Pisaniiu Vetkhogo Zaveta za 1904 god [Notes on the Literature on the Holy Scriptures of the Old Testament, 1904]." TKDA 5 (1905): 124-46; 11 (1905): 413-35.

Solskii, S. M. "Bibliograficheskie zametki: 'Prorok Daniil i Apokalipsis sv. Ioanna.' Sochinenie Oberlena, perevod prot. A. Romanova. Tula. 1882 [Bibliographical Notes: 'The Prophet Daniel and the Apocalypse of St. John.' Text by Oberlen, translated by Prot. A. Romanov. Tula, 1882].” TKDA 6 (1883): 356-68.

Solskii, S. M. "Bibliograficheskie zametki: 'Zhizn Iisusa Khrista' Edmonda Pressane. Chast 2. SPb., 1883 [Bibliographical Notes: Edmond Pressane's 'Life of Jesus Christ.' Part 2. St. Petersburg, 1883]." TKDA 12 (1884):539-58.

Solskii, S. M. "Bibliograficheskie zametki: 'Zhizn i Trudy sviatogo apostola Pavla' Farrara [Bibliographical Notes: Farrar's 'Life and Works of St. Paul the Apostle']." TKDA 1 (1887): 140-52.

Solskii, S. M. "Kratkii ocherk istorii Sviaschennoi bibliologii i ekzegetiki [Overview of the Story of Holy Bibliology and Exegetics]." TKDA 10 (1866): 157-90; 11 (1866): 305-42; 12 (1866): 466-5o6.

Solskii, S. M. "Obozrenie trudov po izucheniiu Biblii v Rossii s XV veka do nastoiashchego vremeni [Review of Research Works on the Bible in Russia from the 15th Century to the Present]." Pravoslavnoe obozrenie 1.2 (1869): 19o-221; 1.4 (1869): 538-77; 1.6 (1869): 797-822.

Solskii, S. M. "Ob uchastii imperatora Aleksandra I v izdanii Biblii na russkom yazyke [The Participation of Aleksandr I in the Publication of the Bible in the Russian Language]." TKDA 1 (1878): 172-96.

Solskii, S. M. "Ostrozhskaia Bibliia v sviazi s tseliami i vidami yeia izdatelia [The Ostroh Bible in Connection with the Intentions and Views of Its Publisher]." TKDA 7 (1884): 293-320.

Solskii, S. M. "Tserkovno-prikhodskaia shkola [The Church Parish School]." TKDA 9 (1886): 146-62. 
Solskii, S. M. "Upotreblenie i izuchenie Biblii v Rossii ot krescheniia Rusi i do 15 v. [The Usage and Study of the Bible in Russia from the Christianization of Rus Through the 15th Century]." Pravoslavnoe obozrenie 27.10 (1868): 145-80; 27.11 (1868): 251-70.

Tsarevskii, A. S. "Bibleiskaia literatura istekshego 1882 goda na zapade. Novyi Zavet [Biblical Literature of 1882 in the West. New Testament]." TKDA 12 (1883): 685-70o. Tsarevskii, A. S. "Bibleiskaia literatura istekshego 1882 goda na zapade. Vetkhii Zavet [Biblical Literature of 1882 in the West. Old Testament]." TKDA 9 (1883):109-22.

Tsarevskii, A. S. "Bibleiskaia literatura istekshego 1883 goda na zapade. Novyi Zavet [Biblical Literature of 1883 in the West. New Testament].” TKDA 12 (1884): 559-86. Tsarevskii, A. S. "Bibleiskaia literatura istekshego 1883 goda na zapade. Vetkhii Zavet [Biblical Literature of 1883 in the West. Old Testament].” TKDA 5 (1884): 103-23.

Tsarevskii, A. S. "Bibleiskaia literatura istekshego 1886 goda na zapade. Novyi Zavet [Biblical Literature of 1886 in the West. New Testament]." TKDA 3 (1887): 425-57. Tsarevskii, A. S. "Bibleiskaia literatura istekshego 1886 goda na zapade. Vetkhii Zavet [Biblical Literature of 1886 in the West. New Testament]." TKDA 12 (1886): 675-712. Voronov, A. "Zametki iz tserkovnoi zhizni Zapada (otritsatelnye napravlenia $\mathrm{v}$ sovremennom khristianstve) [Notes on the Church Life of the West (Negative Trends in Modern Christianity)]." TKDA 6 (1866): 231-54.

Sergiy Golovashchenko, Dr. Hab., is a philosopher and religious scholar. He lectures philosophy and religious studies at the National University of Kyiv-Mohyla Academy. He is the author of Istoriia Khrystyianstva (The History of Christianity, 1999), Bibliieznavstvo (Biblical Studies, 2001), and a research monograph, Doslidzhennia ta vykladannia Biblii $v$ Kyivskii dukhovnii akademii XIX - pochatku XX st. (Research and Instruction of the Bible at the Kyiv Theological Academy in the 19th and Early 2oth Centuries, 2012). Most of his publications explore the history of Biblical studies in Ukraine, particularly at the Kyiv Theological Academy. 